Volume: 6, Issue: 4/ December 2021

\title{
The Investigation of the Relations Between \\ Paternalistic Leadership, Organizational Creativity \\ and Organizational Dissent ${ }^{1}$
}

\author{
Bünyamin A ğalday \\ Mardin Artuklu University, Mardin, Turkey
}

Abidin Dağlı

Dicle University, Diyarbakır, Turkey

\begin{tabular}{lr}
\hline Abstract & $\begin{array}{r}\text { Article } \\
\text { Info }\end{array}$ \\
\hline $\begin{array}{l}\text { The research aims to determine the relationship between public } \\
\text { primary school principals' paternalistic leadership behaviours }\end{array}$ & $\begin{array}{r}\text { Article History: } \\
\text { Received }\end{array}$ \\
and teachers' organizational creativity and organizational & $\begin{array}{c}\text { December 31, 2018 } \\
\text { dissent perception levels according to primary school teachers' }\end{array}$ \\
perceptions. A quantitative correlational design was utilized in & $\begin{array}{c}\text { Accepted } \\
\text { December 20, } 2021\end{array}$ \\
the research. The research sample consists of 1059 public primary & \\
schoolteachers selected by stratified sampling method in Mardin & \\
city center and eight districts of Mardin during the 2016-2017 & Keywords: \\
academic year. The data of the research were obtained by using & Paternalistic \\
the "Headmasters' Paternalistic Leadership Behaviours Scale," & leadership, \\
"Organizational Creativity Scale," and "Organizational Dissent & organizational \\
Scale. "The data analysis revealed the following findings: There & organizational \\
was a positive and significant correlation between the & dissent, primary \\
paternalistic leadership behaviours of primary school & school. \\
administrators and teachers' perceptions toward organizational & \\
creativity and organizational dissent. Also, paternalistic & \\
\hline
\end{tabular}

${ }^{1}$ This study was produced from the first author's doctoral thesis, which was prepared under the supervision of the second author. The study was presented as an oral presentation at the V. International Eurasian Educational Research Congress. 
leadership behaviours of primary school administrators were found to be a significant predictor of teachers' perceptions toward organizational creativity and organizational dissent. The principals should exhibit benevolent leadership behaviours that enhance the teachers' organizational creativity perceptions, such as endeavouring to create a family milieu in school, being tolerant of teachers, and supporting teachers to take the initiative.

\section{Cite as:}

Ağalday, B. \& Dağlı, A. (2021). The investigation of the relations between paternalistic leadership, organizational creativity and organizational dissent. Research in Educational Administration \& Leadership, 6(4), 748-794. DOI: 10.30828/real/2021.4.1

\section{Introduction}

Like all organizations, educational organizations also need a leader and leadership to realize organizations' objectives. Various studies have put forward the influence of leadership in the success of educational organizations (Gunter, 2001; Lakomski, 2008; Leithwood \& Jantzi, 1999; Sillins \& Mulford, 2002). When those studies on leadership in schools as educational organizations have been examined, it is seen that school principals are generally the focal points of the studies. On the other hand, it is seen in many studies (Dimmock, 1999; Fullan, 2002; Hallinger, 2003; Harris, 2004; Jones, 1999; Leithwood, Steinbach \& Ryan, 1997; Timperley\& Robinson, 2001) that the leadership role of the school principals, who are perceived as the pioneers of the innovative practices in schools, is constantly changing. The complexity of the functions of school principals causes the variety of leadership styles they need (Young, 1994: 44). While Western leadership styles such as distributed leadership, charismatic leadership, and transformational leadership are frequently discussed in educational organizations, paternalistic leadership (PL) style of eastern origin, which is considered within the scope of this research, 
has started to be discussed in non-educational organizations in recent years. The differences in Eastern and Western cultures show that there is a need to investigate the leadership styles of school principals in a particular cultural context.

PL has been put forward as one of the leadership approaches that followers expect of the leaders (Pellegrini \& Scandura, 2006), in countries with high collectivism and power distance, such as Turkey (Aycan \& Kanungo, 2000; Hofstede, 2006). Being a collectivist country with a high power distance and extensive family orientation has helped PL become a convenient management style for Turkey (Ersoy, Born, Derous \& Molen, 2012; Pellegrini and Scandura, 2006). According to the findings of several studies (Aycan, 2001; Aycan \& Kanungo, 2000; Paşa et al., 2001), Turkey ranks among the countries with high scores of paternalism, and employees in Turkey expect the leader or the manager to be paternalistic. In various studies, albeit limited, conducted in Turkish schools (Aydıntan, 2016; Cerit, 2012; 2013; Cerit, Özdemir \& Akgün, 2011; Dağlı \& Ağalday, 2018; Mert \& Özgenel, 2020; Mete \& Serin, 2015; Özgenel \& Dursun, 2020), it can be stated that teachers expect paternalistic leadership behaviours from their principals, such as care, support and protection, constant communication and close personal interaction. Studies in Turkey demonstrate that PL significantly affects employees' commitment (Erben \& Güneşer, 2008) and performance (Hatipoğlu, Akduman \& Demir, 2019). Studies conducted in Turkish schools have also shown that PL has significant effects on some organizational variables. For instance, it has been reported that paternalistic leadership affects teachers' perceptions positively regarding organizational happiness (Özgenel \& Canulansı, 2021), creative leadership (Taşdemir \& Atalmış, 2021), school culture (Özgenel \& Dursun, 2020), organizational trust and motivation (Okçu, Ergül \& Ekmen, 2020), teacher performance (Mert \& 
Özgenel, 2020), teachers' participation in decision making and teachers' trust in principals (Cansoy, Polatcan \& Parlar, 2020), organizational citizenship (Mete \& Serin, 2015) and job satisfaction (Cerit, 2012; Ekmen \& Okçu, 2021). In addition to its positive effects, it is thought that paternalistic leadership, which envisages professional support of those in the organization, may have different positive effects on teachers, such as creativity.

In Turkish schools managed with a central education system, the support of teachers by school principals can improve their creativity because leaders are influential in forming an organizational culture that nurtures creative efforts and facilitates the spread of learning throughout the Organization (Yukl, 2010). Therefore, school principals' paternalistic attitudes may facilitate teachers' creative endeavours. Studies have shown that leadership affects creativity in organizations (Mumford, Ginamaire, Gaddis, \& Strange, 2002; Mumford \& Connelly, 1999; Oldham \& Cummings, 1996; Redmond, Mumford \& Teach, 1993; Scott \& Bruce, 1994). In this context, how paternalistic school principals will affect teachers' perceptions of creativity is considered as one of the factors that will make this research necessary. However, school principals may exhibit authoritarian behaviours as a result of centralism. Therefore, teachers may feel uncomfortable with the authoritarian approach. Teachers may also display a dissident attitude by expressing their discomfort. On the one hand, teachers whose autonomy level will increase because they are supported (Chou, 2012) will display a creative attitude; on the other hand, they may display dissident behaviour in cases where they need to make independent decisions, since their autonomy may be restricted (Miller \& Wertheimer, 2007). However, it can be argued that with the favourable climate created by being supported, teachers will more easily express their contradictory views. Therefore, school 
principals' paternalistic leadership behaviours may directly or indirectly cause teachers to display oppositional behaviours. Moreover, whether the paternalistic behaviours of the principal have anything to do with the dissident manner that teachers exhibit is another point that will render this research significant. Determination of the PL behaviours of principals, which may cause teachers to exhibit dissident behaviours and take measures against them, can contribute to the adoption of democratic elements in the school and the development of positive behaviours of teachers towards school.

It might be deemed essential to examine the relationship of the PL approach with organizational creativity and organizational dissent to develop organizational creativity and let the behaviours that are needed to be displayed by the principals' ineffective dissent management be discovered. When considered from this point of view, the relationship between the PL behaviours of the school principals and the organizational creativity and organizational dissent levels of teachers can be examined. Therefore, it can be stated that the specification of the organizational variables related to PL is essential. When the literature is reviewed, a few studies (e.g., Anyanwu \& Oad, 2016; Inand1, Tunc, Yucedaglar \& Kilic, 2020; Riaza, Junejo \& Shar, 2020) have been conducted on the relationship between different leadership styles and organizational creativity and organizational dissent. When the leader-organization relationship is examined, it is thought that paternalistic leadership has a relationship with organizational creativity and organizational dissent. However, no research analyzing the relationship between PL and organizational creativity and organizational dissent has been encountered. In this regard, this research is also essential in filling the relevant gap in the literature. The paternalistic leadership style is one of the leadership styles suitable for the cultural norms of Turkish society, which has a 
high power distance and collectivist cultural characteristics. In this context, it is crucial to investigate the effects of the paternalistic leadership style of school principals on teachers in the Turkish education system, which is managed with a centralized approach. This research seeks to examine the connection between the organizational creativity and organizational dissent perceptions of teachers, which are thought to be relevant to the paternalistic leadership behaviours of school principals. This research is expected to benefit the school managers who participate in the practice, teachers, and researchers who will research this topic.

\section{Paternalistic Leadership}

PL is a relatively new concept in the leadership and management literature. Rooted in "Confucian Philosophy," with approximately 2000-year-old influence on the Chinese management (Cheng, Chou, Wu, Huang \& Farh, 2004; Farh \& Cheng, 2000), PL is identified as a style in which strong discipline and authority are merged with a paternalistic benevolence and moral integrity in a personal setting (Farh \& Cheng, 2000). Based on intercultural leadership, this leadership style has been put into practice effectively in countries outside of North America, such as Taiwan (Farh \& Cheng 2000; Cheng et al., 2004), China (Farh, Cheng, Chou \& Chu, 2006; Sheer, 2012), Mexico (Martinez, 2003), Japan (Uhl-Bien, Tiemey, Graen\& Wakabayashi, 1990), Korea (Kim, 1994), India (Aycan, Kanungo \& Sinha, 1999; Pellegrini, Scandura \& Jayaraman, 2010), and Turkey (Pellegrini \& Scandura, 2006).

When studies about the dimensions of PL have been examined in the literature, it is seen that two primary classifications were discussed the most. Those include the study made by Farh and Cheng (2000), analyzing paternalistic leadership in the dimensions of 
"benevolent leadership," "moral leadership," and "authoritarian leadership," and the study by Kim (1994) analyzing paternalistic leadership in the dimensions of "benevolent" and "exploitative. "In benevolent leadership, it is essential that the leader shows individualized, long-term, and holistic concern to followers for their good and wellbeing. Benevolent actions include behaviours such as the leader taking an interest in the personal and family issues of the followers, protecting and forgiving them for their good and well-being, along with the leader showing individualized, long-term, and holistic concern to the followers (Aycan \& Fikret-Paşa, 2003; Erben \& Güneşer, 2008). In moral leadership, it is, to a large extent, important that the leader has personal integrity, improves himself, and does not only think of himself (Westwood, 1997). Moral actions include not being selfish, honest, and responsible, being a model, and not mixing personal interests with business relations (Cheng, Chou \& Farh, 2000). In authoritarian leadership, the leader asserts their unquestionable and absolute authority, takes control over subordinates firmly, and demands complete obedience from them. Power and hegemony, underestimation of the talents of subordinates, projection of the 'supreme' image for the leader, and giving instructions to employees in a didactic way exist among the concrete examples of behaviours describing authoritarian leadership (Cheng, 1995). In exploitative leadership, the ultimate aim of the leader is to earn the obedience of the employee in exchange for the attention given, and the leader's priority is the organizational assets (Hayek, Novićević, Humphreys \& Jones, 2010). In exploitative leadership, subordinates show respect and loyalty to the superior to avoid penalty or receive reward (Kim, 1994; Pellegrini \& Scandura, 2006). When examined from a general perspective, it can be stated that followers occur at the center of 
benevolent and moral leadership. At the same time, the organization takes place at the center of authoritarian and exploitative leadership.

Having developed her model based on the dimensioning made by Kim (1994) regarding the PL, Aycan (2006) has attempted to explain PL behaviours by comparing authoritarian and autocratic leadership approaches concerning the benevolent and exploitative paternalism dimensions. In benevolent paternalism, the superior improves the well-being of the subordinate by taking an interest in the subordinate, and in return, the subordinate shows loyalty to the excellent. In exploitative paternalism, there is an interest given to the subordinate by the superior, as was the case with benevolent paternalism. Yet, this interest envisages the compliance of the subordinate for the fulfilment of organizational objectives. In authoritarian approach, the subordinates are obliged to comply with the exploitative and controlling behaviours of the superior with an expectation of a reward or to avoid penalties. Even though there is control in the autocratic approach, the well-being of the subordinate takes precedence. In this case, the subordinate tends to respect the decisions made by the superior and follow the rules since they know that it is for one's good. According to the model, the key feature distinguishing "exploitative" and "benevolent" dimensions of paternalism lies with the power motivating the behaviours of the subordinate and the superior.

\section{Organizational Creativity}

When studies conducted on the concept of creativity (Amabile, Conti, Coon, Lazenby \& Herron, 1996), which is described as the production of new and useful ideas in every field, are examined, it is observed that creativity is primarily tackled at an individual level (İraz, 2010) while it is also a concept discussed at an organizational level due to the existence of the human factor (Bharadwaj \& Menon, 
2000). While the notion of creativity falls into management and organizational studies, organizational creativity has been put forward to focus on the analysis of creativity in organizations (Basadur, 1997; Ford, 1996; Woodman, Sawyer \& Griffin, 1993). Organizational creativity has been addressed at the organizational level by generally referring to producing new, valuable, practical, or valuable ideas (Amabile, 1988), goods, processes, or services (Scott \& Bruce, 1994; Woodman et al., 1993) in an organization.

Organizational creativity as a research field has been developing at a fast pace in recent years. Studies on organizational creativity started actively in the late 1980s, but academic interest in the subject has increased rapidly in the late 2000s (James \& Drown, 2012; Shalley \& Zhou, 2008). Even though the notion of creativity has been studied under different frameworks in the literature, which include organizational creativity (Amabile, 1996; Andriopoulos, 2001; Woodman et al., 1993), collective creativity (O'Donnell et al., 2006), creativity in organizations (Amabile, 1997; Drazin et al., 1999; Driver, 2008), creative joint venture (Hargadon \& Bechky, 2006), and distributed creativity (Sawyer \& DeZutter, 2009), all of those concepts correspond to the notion of organizational creativity.

Organizational creativity is usually defined as producing new and valuable, sound, or good ideas (Amabile, 1988), goods, processes, or services (Scott \& Bruce, 1994; Woodman et al., 1993). This definition highlights the societal aspect of creativity, the complexity of the societal processes, and various contextual and situational effects. In addition to this, organizational creativity is affected by formal organizational practices, structural factors, and managerial issues (Andriopoulos, 2001; Bharadwaj \& Menon, 2000; Kallio \& Kallio, 2011; Styhre \& Sundgren, 2005). There are also studies (Agrell \& Gustafson, 
1994; Oldham \& Cummings, 1996) operationalizing organizational creativity as the simple aggregation of the individual creativities in the organization.

\section{Organizational Dissent}

It is seen that the notion of dissent as a research topic of Political Science has lately started to be studied in the fields of organization and management. Dissent is a concept related to the person feeling incongruous (Kassing, 1997a). In the organizational context, dissent is defined as voicing several conflicts and opposing views by the employees (Kassing, 1997a; 2002). The process of organizational dissent starts with a triggering event. Dissent occurs when a triggering event exceeds the individual's tolerance limits (Redding, 1985). A triggering event is not a sufficient condition for organizational dissent to start. For members of the organization to voice their opposing ideas, first and foremost, they need to comprehend that there is a problem within the organization. They need to find this problem worthy of intervening in (Graham, 1986). Even though a difference of opinion between the members of the organization and their superiors is not deemed sufficient to speak of an organizational dissent, there needs to bean articulation of the relevant difference of opinion.

When members of the organization face several harmful practices, they choose a particular dissent strategy to voice their contradictory ideas. Those strategies consist of articulated dissent, latent dissent, and displaced dissent strategies (Kassing, 1997a). Articulated dissent happens when members of the organization state their contradictory views to people who can affect the balances in the Organization (Kassing, 1997a; 1998; Kassing \& Avtgis, 1999). In this strategy, members of the organization express their contradictory views to their managers directly or indirectly (Kassing, 2002). 
According to the latent dissent strategy, the organization member shares their contradictory thoughts with generally other members of the organization who do not predict the balances within the Organization (Kassing, 1997a). Latent dissent behaviour essentially emerges when the members of the organization think of themselves perceived as an enemy or a rival within the Organization (Kassing, 1998). In this case, members of the organization do not articulate their contradictory views with the apprehension that their interests might be damaged. This causes members of the organization to be silent or express their contradictory views to their co-workers (Kassing \& Avtgis, 1999). Displaced dissent occurs when the members of the organization prefer to convey their contradictory ideas to people outside of the Organization (Kassing, 1997a, p.326; Kassing \& Avtgis, 1999). Those people include friends, spouses, partners, and family members of the organization.

Organizational dissent as a research topic has been tackled in the literature, mostly in private or public sector organizations. However, there are very few studies in the literature on the

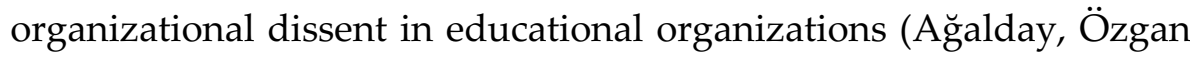
\& Arslan, 2014; Atmaca, 2021; Dağlı \& Ağalday, 2014a; 2014b; Dağlı, 2015; 2017; Dağlı \& Ağalday, 2015; Korucuoğlu \& Şentürk, 2020; Özdemir, 2010; Yıld1z, 2013). The study conducted by Özdemir (2010) with a claim to reconceptualize organizational dissent in the school environment in terms of micro politics stands out as the first study in the literature that addresses teacher dissent at the level of managerteacher relations. When the studies conducted abroad (Bell-Robinson, 2016; Bouda, 2015; Burns \& Wagner, 2013) are examined, it has been considered striking that those studies carried out in the United States of America are predominantly focused on the organizational dissent perceptions of the students. 


\section{The Relationship Between Paternalistic Leadership and Organizational Creativity}

There has been no research encountered in the literature addressing the relationship between paternalistic leadership and organizational creativity. Therefore, findings of different studies that can be considered relevant and theoretical frameworks of paternalistic leadership and organizational creativity have been considered. At the same time, the correlation between respective variables was analysed. Leadership is one of the most critical factors determining the development of creativity in organizations (Atwater \& Carmeli, 2009; Mumford, Ginamaire, Gaddis \& Strange, 2002; Volmer, Spurk \& Niessen, 2012). In other words, the characteristics of leadership displayed at the organizational level have been identified as one of the critical variables explaining organizational creativity (Einsteine \& Hwang, 2007). Organizational creativity has been gradually growing into an exciting field for leaders. They play a significant role in creativity in the context of work. Leaders can affect employees' creativity with their behaviours by influencing employees' perceptions in their working environment (Amabile, Schatzel, Moneta \& Kramer, 2004). In the studies made, it is found that leadership affects creativity in the organizations (Mumford et al., 2002; Mumford \& Connelly, 1999; Oldham \& Cummings, 1996; Redmond, Mumford \& Teach, 1993; Scott \&Bruce, 1994). Leaders have a meaningful impact on creativity since they identify and shape the job status in organizations in the context of employees interacting with each other (Amabile, 1998). It is found that the perceived support of a leader has a significant influence on the employees' creativity (Amabile et al., 2004). Leaders are influential in forming an organizational culture (Ekvall, 1996; Ekvall \& Ryhammar, 1998; Schein, 2004) that fosters creative efforts and facilitates the spread of teaching to the entire organization (Yukl, 2010). Leaders can also 
develop systems that evaluate and reward creative performance through various channels, increasing the employees' willingness for creative work (Jung, 2001). In other words, leaders can contribute to the development of creativity of their followers by affecting their motivation.

Individual and organizational factors developing or limiting creativity have been examined in some empirical studies (Amabile et al., 2004; Atwater \& Carmeli, 2009; Oldham and Cummings, 1996; Redmond, Mumford \& Teach, 1993; Scott \& Bruce, 1994; Shin and Zhou, 2003; Tierney, Farmer \& Graen, 1999). The main finding of these studies is that a supportive and encouraging working environment is usually positively correlated with creativity. From this point of view, it can be said that leaders who are supportive and are not controldriven increase the creative contribution of the employees to their work. It has been put forward that PL anticipates supporting employees vocationally (Aycan \& Fikret-Paşa, 2003; Erben \& Güneşer, 2008; Gelfand, Erez \& Aycan, 2007), will contribute to the increase in the autonomy levels of the employees (Chou, 2012). Therefore, it is expected that there is a relationship between PL behaviours of school principals and organizational creativity levels of teachers.

\section{The Relationship Between Paternalistic Leadership and Organizational Dissent}

It can be stated that the followers tend to display independent behaviours (Mayer, Davis \& Schoorman, 1995; McKnight, Cummings \& Chervany, 1998), will react to the paternalistic behaviours, which leaders will exhibit because it is asserted that the paternalistic understanding can limit the autonomy of the followers in cases of the instances of autonomous decision-making (Miller \& Wertheimer, 2007). Redding (1990) states that independent and autonomous 
employees will reject paternalistic behaviours. Paternalistic leaders ask the employees about their ideas (Kabasakal \& Bodur, 1998), yet the leader reserves the right to make the last decision (Aycan et al., 2000). In this case, even though the employees participate in the stages of getting opinions and creating goals, implementation of the ideas of the employees is not required in the paternalistic management style (Aycan \& Kanungo, 2000; Erben, 2004). It is suggested that dissent can emerge due to managers not including their employees in the organizational decisions (Kassing, 1998). In such a case, it is likely that the employees whose autonomy is restricted, even partially, and who see their ideas are not implemented display dissident behaviours.

Another behaviour of the paternalistic leader that can lead to dissent of the follower is related to the leader not being fair. While the paternalistic leader distributes his/her "authority" or "benevolence" to his/her employees, s/he may not be fair or neutral (Redding, 1990), or $\mathrm{s} /$ he can give priority to family ties and a sense of security, instead of competence and expertise (Develi, 2008). This can turn the style of PL into discrimination (Aycan, 2001; Aycan, 2006; Çalışkan, 2010; Erben, 2004). Hegstrom (1991) states that privileges granted to the employees and the duties and responsibilities in the organization can lead to dissent. Another behaviour of the paternalistic leader that can result in the dissent of the employees is the possibility of the leader ignoring his responsibilities and losing his/her interest in his/her employees. This situation is criticized since it will cause the paternalistic leader to become autocratic (Pellegrini, Scandura \& Jayaraman, 2010). It is seen that some paternalistic practices of leaders, as mentioned above, can cause employees to dissent. Hence, there is likely a relationship between PL behaviours of school principals and organizational dissent perception levels of teachers. 


\section{The Purpose of the Research}

The purpose of the research is to examine the relationship between PL behaviours of the primary school principals and organizational creativity and organizational dissent perception levels of teachers based on the teachers' perceptions. Following this purpose, answers are sought for the research questions below:

1. Are the perceptions of primary school teachers on the PL behaviours of the school principals meaningful predictors of organizational creativity?

2. Are the perceptions of primary school teachers on the PL behaviours of the school principals meaningful predictors of the organizational dissent?

\section{Methodology}

\section{Research Design}

A quantitative correlational design was employed in this research to examine the relationship between paternalistic leadership, organizational creativity, and organizational dissent.

\section{Sample}

The research population consists of the central Artuklu district of the province of Mardin in the 2016-2017 academic year and 2597 public primary schoolteachers in affiliated eight district centers. Considering the difficulty of reaching the whole population, stratified sampling method was used (Fraenkel, Wallen\& Hyun, 2012). Accordingly, each of the districts of Mardin was sampled. In the sample selection, the ratio of the number of primary school teachers in the districts to the total number of teachers in the population was taken into consideration. For example, there are 602 teachers in the Artuklu 
district. This number constitutes $23.19 \%$ of the number of teachers in the population. To determine the number of samples, $23.19 \%$ of the 1100 number was calculated, and the number 255 was obtained. For all districts, the ratio represented by the number of teachers in the district in the population was calculated, and scale forms were distributed to the districts by considering this rate. The 92 schools and teachers sampled in the lower levels were determined by the simple random sampling method. We have access to all schools and teachers' names and then randomly select from this list. Incorrect or incomplete returned forms were left, and 1059 scale forms were evaluated. Of the teachers participating in the research,3.2\% were associate degrees, 93.2\% were undergraduate degrees, and $3.6 \%$ were graduate degrees. Among the participants, $50.9 \%$ were female, and $49.1 \%$ were male, which closely represents the gender distribution of teachers in Turkey (Çelik, Yurdakul, Bozgeyikli, \& Gümüş, 2017). While $64.6 \%$ of the teachers were married, $35.4 \%$ were single. Among the teachers, $42.8 \%$ had less than five years of experience, while only $6.5 \%$ had more than 20 years of experience.

\section{Scales of Measurement}

Research data were obtained by the use of "Headmasters' Paternalistic Leadership Behaviours Scale," which was developed by Dağlı and Ağalday (2017), "Organizational Creativity Scale" which was developed by Çavuş (2006) and was adapted to schools by Yılmaz and Sünbül (2008), and "Organizational Dissent Scale" which was developed by Kassing (2000) and adapted to Turkish by Dağlı (2015).

\section{Headmasters' Paternalistic Leadership Behaviours Scale (HPLBS)}

The scale consists of 22 items and four dimensions (benevolent leadership, moral leadership, authoritarian leadership, exploitative 
leadership). This 5-point Likert-type scale was answered on a rating scale from 1 ("completely disagree") to 5 ("completely agree"). In this study, the first level CFA was done for the scale. Sample items from the scale include "My headmaster approaches teachers like a parent and guards them" and "My headmaster takes care of teachers' private problems." CFA results revealed that the fit indices of the scale were consistent with the original form $\left(\chi^{2} / \mathrm{df}=4.96[<5], \mathrm{CFI}=.94\right.$ [>.90], GFI $=.92[>.90]$, RMSEA $=0.06[<.08], \mathrm{NFI}=0.93$ [>.90], and IFI= $0.93[>.90])$. The Cronbach Alpha coefficient has been found in the study as .95 for benevolent leadership, .82 for moral leadership, .72 for authoritarian leadership, .71 for exploitative leadership, and .92 for the whole scale. These findings demonstrate that the scale is a valid and reliable tool.

\section{Organizational Creativity Scale (OCS)}

The scale consists of 21 items, of which all of the items fall under one dimension, presented in a five-point Likert-type scale $(1=$ never disagree, $5=$ totally agree). Sample items from the scale include "Learning is encouraged in our school" and "The level of knowledge sharing is high in our school. "In this study, CFA was done for the Organizational Creativity Scale. The fit indices $\left(\chi^{2} / \mathrm{df}=2.94[<5], \mathrm{CFI}\right.$ $=.95[>.90]$, RMSEA $=.06[<.08], \mathrm{NFI}=.93$ [>.90], and IFI $=.95[>.90])$ show that the model fits well. In the study, the Cronbach Alpha coefficient has been found as .95. These data demonstrate that the scale is a valid and reliable tool.

\section{Organizational Dissent Scale (ODS)}

While Dağlı (2015) adapted the scale to Turkish, he has first addressed the study of Turkish validity and reliability, then the construct validity. A high, positive, and meaningful correlation has been identified between English and Turkish scales in terms of linguistic equivalence $(\mathrm{r}=.97 ; p=.00)$. The scale consists of 15 items, of 
which eight items constitute upward dissent and seven items constitute latent dissent. Sample items from the scale include "I hesitate to query school policies" and "I criticize the inadequacies in my school in front of everyone. "This scale was answered on a rating scale from 1 ("never disagree") to 5 ("fully agree"). In the study, CFA was done for the Organizational Dissent Scale. It was found that the fit index values $\left(\chi^{2}\right.$ $/ \mathrm{df}=2.83[<5], \mathrm{CFI}=.94$ [>.90], GFI = .90 [>.90], RMSEA $=.07[<0.08]$, $\mathrm{NFI}=.91[>0.90]$, and IFI $=.94[>0.90])$. Considering these criteria, it can be argued that the two-factors structure obtained from CFA is an acceptable model. In this study, the Cronbach Alpha coefficient has been found as .81 for the first factor, .72 for the second, and .82 for the whole scale. These coefficients demonstrate that the scale is a reliable tool.

\section{Data Analysis}

The use of SPSS software has analyzed research data. Correlation and multiple linear regression analyses have been applied to examine the relationship between PL, organizational creativity, and organizational dissent. The skewness and kurtosis coefficients of the data set were examined to determine the normality. The skewness coefficients of the HPLBS are between .65 and .06; kurtosis coefficients vary between -.81 and -.24 . The skewness coefficients of OCS are between -.73 and -.19 ; kurtosis coefficients vary between -.75 and -.24. The skewness coefficients of ODS are between -.54 and -.11; kurtosis coefficients vary between -.73 and -.16. These values indicate that the data show a distribution close to normal (Kline, 2011). In this study, the suitability of the factor structure of the data collection tools has been tested by CFA. Multicollinearity issue was not observed between variables (see Table 1). 


\section{Results}

We found positive correlation between the variables studied. The findings showed a strong level of correlation between organizational creativity and paternalistic leadership $(\mathrm{r}=.70 ; p<.01)$ and between organizational creativity and organizational dissent $(\mathrm{r}=$ $.72 ; \mathrm{p}<.01)$, while between paternalistic leadership and organizational dissent $(\mathrm{r}=.29) ; \mathrm{p}<.01)$ showed low levels of correlations. Accordingly, as teachers' perceptions of paternalistic leadership increase, their perceptions of organizational creativity and organizational dissent also increase.

Table 1.

Correlation Among Variables

\begin{tabular}{lllllllllll}
\hline Variable & BL & ML & AL & EL & PL & OC & UD & LD & O \\
\hline
\end{tabular}

\begin{tabular}{lcccccccc}
\hline BL & - & & & & & & \\
\hline ML & $.68^{* *}$ & - & & & & & \\
\hline AL & $.40^{* *}$ & $.40^{* *}$ & - & & & & \\
\hline EL & $.20^{* *}$ & $.35^{* *}$ & $.54^{* *}$ & - & & & & \\
\hline PL & $.79^{* *}$ & $.75^{* *}$ & $.65^{* *}$ & $.51^{* *}$ & - & & & \\
\hline OC & $.76^{* *}$ & $.57^{* *}$ & $.31^{* *}$ & $.15^{* *}$ & $.70^{* *}$ & - & & \\
\hline UD & $.37^{* *}$ & $.40^{* *}$ & $.28^{* *}$ & $.20^{* *}$ & $.43^{* *}$ & $.41^{* *}$ & - & \\
\hline LD & .06 & $.07^{*}$ & -.05 & $-.10^{* *}$ & .02 & $.11^{* *}$ & $.41^{* *}$ & - \\
\hline OD & $.27^{* *}$ & $.29^{* *}$ & $.15^{* *}$ & $.07^{*}$ & $.29^{* *}$ & $.32^{* *}$ & $.86^{* *}$ & $.81^{* *}$ \\
\hline
\end{tabular}

BL: Benevolent Leadership, ML: Moral Leadership, AL: Authoritarian Leadership, EL: Exploitative Leadership, PL: Paternalistic Leadership, OC: Organizational Creativity, UD: Upward Dissent, LD: Latent Dissent ${ }^{*} p<.05,{ }^{* *} p<.01$

In the second part of the analysis, we examined the predictive power between the variables. First, we performed a multiple linear 
regression analysis in which the sub-dimensions of paternalistic leadership were independent and organizational creativity was the dependent variable. The results are presented in Table 2.

Table 2.

Multiple Linear Regression Analysis concerning the Prediction of Organizational Creativity by Paternalistic Leadership Dimensions (Dependent variable $=$ Organizational creativity)

\begin{tabular}{lccccc}
\hline Variable & $B$ & S.E. & $\beta$ & $t$ & $p$ \\
\hline Constant & .85 & .90 & & 9.71 & $.00^{*}$ \\
Benevolent Leadership & .60 & 1.04 & .70 & 25.18 & $.00^{*}$ \\
Moral Leadership & .10 & .88 & .10 & 3.76 & $.00^{*}$ \\
Authoritarian Leadership & -.00 & 1.09 & .00 & -.14 & .89 \\
Exploitative Leadership & -.02 & 1.04 & .02 & -.11 & .25 \\
\hline$R=.76 ; R^{2}=.58 ; F=380.13 ; p=.00$ & & & & & \\
$*: p<.01$ & & & & &
\end{tabular}

Analysis results showed that paternalistic leadership displayed a significant relationship $\left(R=.76 ; R^{2}=.58\right)$ with organizational creativity $(F=380.13 ; p<.01)$. Dimensions of paternalistic leadership explain $58 \%$ of the change in organizational creativity. Based on standardized regression coefficients, the order of importance of the predictive variables on teachers' organizational creativity perception levels follows as benevolent leadership $(\beta=.70)$ and moral leadership $(\beta=.10)$. Benevolent leadership had a strong effect, while moral leadership had a weak effect. The analysis results regarding the prediction of upward dissent by the dimensions of paternalistic leadership are presented in Table 3. 
Table 3.

Multiple Linear Regression Analysis concerning the Prediction of Upward Dissent by Paternalistic Leadership Dimensions

\begin{tabular}{lccccc}
\hline (Dependent variable =Upward dissent) & & & & & \\
\hline Variable & $B$ & S.E. & $\beta$ & $t$ & $p$ \\
\hline Constant & 2.40 & .75 & & 23.51 & $.00^{*}$ \\
Benevolent Leadership & .11 & 1.04 & .15 & 4.03 & $.00^{*}$ \\
Moral Leadership & .21 & .87 & .24 & 6.27 & $.00^{*}$ \\
Authoritarian Leadership & .07 & 1.09 & .11 & 3.15 & $.00^{*}$ \\
Exploitative Leadership & .01 & 1.04 & .02 & .68 & .49 \\
\hline
\end{tabular}

$R=.44 ; R^{2}=.19 ; F=64.78 ; p=.00$

$* p<.01$

Results concerning multiple linear regression analysis are shown in Table 3. The results showed that paternalistic leadership displayed a significant relationship $\left(R=.44, R^{2}=.19\right)$ with upward dissent $(F=64.782, p<.01)$. Dimensions of paternalistic leadership explain $19 \%$ of the change in upward dissent. The order of importance of the predictive variables on the upward dissent follows as moral leadership ( $\beta=.24$ ), benevolent leadership $(\beta=.15)$, and authoritarian leadership $(\beta=.11)$. The dimensions had a weak effect. The analysis results regarding the prediction of latent dissent by the dimensions of paternalistic leadership are presented in Table 4. 
Table 4.

Multiple Linear Regression Analysis concerning the Prediction of Latent Dissent by Paternalistic Leadership Dimensions

\begin{tabular}{lccccc}
\hline \multicolumn{4}{c}{ (Dependent variable $=$ Latent dissent) } \\
\hline Variable & $B$ & S.E. & $\beta$ & $t$ & $p$ \\
\hline Constant & 3.33 & .75 & & 23.51 & $.00^{*}$ \\
\hline $\begin{array}{l}\text { Benevolent } \\
\text { Leadership }\end{array}$ & .01 & 1.04 & .02 & 4.03 & .58 \\
\hline $\begin{array}{l}\text { Moral } \\
\text { Leadership }\end{array}$ & .10 & .87 & .12 & 6.27 & $.00^{*}$ \\
\hline $\begin{array}{l}\text { Authoritarian } \\
\text { Leadership }\end{array}$ & -.03 & 1.09 & -.05 & 3.15 & .19 \\
\hline $\begin{array}{l}\text { Exploitative } \\
\text { Leadership }\end{array}$ & -.08 & 1.04 & .02 & .68 & $.00^{*}$ \\
\hline $\begin{array}{l}R=.15 ; R^{2}=.02 ; F=6.87 ; p=.00 \\
*: p<.01\end{array}$ & & & &
\end{tabular}

When Table 4 is examined, analysis results showed that paternalistic leadership displayed a significant relationship $\left(R=.15, R^{2}\right.$ $=.02)$ with latent dissent $(F=6.87, p<.01)$. Dimensions of paternalistic leadership explain $2 \%$ of the change in latent dissent. The order of importance of the predictive variables on the latent dissent follows as moral leadership $(\beta=.12)$ and exploitative leadership $(\beta=.02)$. The dimensions had a weak effect.

\section{Discussion, Conclusion, and Suggestions}

This research examines relationships between paternalistic leadership, organizational creativity, and organizational dissent based on teachers' perceptions. The findings obtained are researched within the scope of the relevant literature and discussed within their context. Suggestions towards practitioners and researchers are generated regarding the results obtained in the wake of the discussion. 
When the findings related to the first research question of the study are examined, only benevolent leadership and moral leadership subdimensions of PL are meaningful predictors of organizational creativity. It can be expressed that the principals' PL behaviours have essential and profound effects on the teachers' organizational creativity perception levels. Also, the importance of the predictive variables on the teacher's organizational creativity perception levels follows as benevolent leadership and moral leadership. Among the sub-dimensions of primary school principals' PL behaviours, the benevolent leadership dimension can be said to constitute the most critical effect on the teachers' organizational creativity perception levels. While there has been no study encountered in the literature addressing the relationship between PL and organizational creativity, studies are managing the relationship between the sub-dimensions of PL and the creativity of employees in the organizations $(\mathrm{Gu}$, Tang \& Jinag, 2015; Kurt, 2013; Sheer, 2010; Wang \& Cheng, 2010; Wang, Kuo, Cheng \& Tsai, 2009). When the findings obtained from those studies are examined in general terms, it is seen that only benevolent leadership and moral leadership dimensions among the subdimensions of PL are positively correlated with creativity and have an association with creativity. From this aspect, it can be expressed that the findings obtained from the present study bear a resemblance to the results obtained from mentioned studies. The benevolent leader can cause an increase in the employees' creativity levels since the leader contributes to the formation of an environment of trust in the organization psychologically by providing social support through assisting the employees in any kind of problem (Tierney et al., 1999). It is seen in research conducted that the school managers' PL behaviours have a significant impact on the teachers' organizational trust perceptions (Karasel, Altınay, Altınay \& Dağlı, 2017). The benevolent 
leader acknowledges the role of his follower as both a model subordinate and a valuable person (Farh \& Cheng, 2000). The subordinates who perceive these acknowledgments then experience a sense of gratitude (Cheng et al., 2004) that facilitates interpersonal trust and the level of comfort required for creativity (Mumford \& Gustafson, 1988). In addition to this, it is suggested that the subordinates with high benevolent leadership perception are transferred more funds by their leaders and appreciated more (Farh \& Cheng, 2000). From this point of view, it can be suggested that the benevolent leader is more sensitive to creativity and supports creativity. Besides that, it is also probable that the moral leadership which anticipates keeping the employees vocationally (Gelfand et al., 2007) affects their creativity. Tolerance of the moral leader affects the behaviours of the followers and contributes to the increase in their morale and motivation (Niu, Wang \& Cheng, 2009). Given that motivation is a factor influencing creativity, it is thought that the obtainment of the findings in the present research can be explained with this situation as well. If there is trust in the relationship between the leader and the follower, and if it is not spoiled, the relationship, by nature, turns into a social transaction by the leader adopting benevolent and moral leadership (Chen, Eberly, Chiang, Farh \& Cheng,2011). This mentioned social transaction is considered to contribute to the increase in the employees' creativity.

When the findings related to the second research question of the study are examined, it is seen that only the benevolent leadership, moral leadership, and authoritarian leadership sub-dimensions of PL are meaningful predictors of upward dissent. Also, the order of importance of the predictive variables on the teachers' upward dissent perception levels follows as moral leadership, benevolent leadership, and authoritarian leadership. Among the sub-dimensions of primary school principals' PL behaviours, the moral leadership dimension can 
most critically affect teachers' upward dissent perception levels. In addition to this, it is seen that only the moral leadership and exploitative leadership sub-dimensions of PL are meaningful predictors of latent dissent. Also, the order of importance of the predictive variables on the teachers' latent dissent perception levels follows as moral leadership and exploitative leadership. Among the sub-dimensions of primary school principals' PL behaviours, the moral leadership dimension can constitute the most critical effect on the teachers' latent dissent perception levels, as is the case with upward dissent.

In the present study, it is identified that within the scope of benevolence, the primary school principals assist teachers in any problems within or outside of the school domain by creating a family milieu. They also work with the teachers in harmony; they tolerate teachers and support them in taking the initiative. These kinds of behaviours displayed by the principals are considered to positively influence thought to be reflecting simply on the communication between the principal and teachers as they affect the democratic environment in the school. This way, it can be suggested that teachers can articulate their opinions in a more accessible and more comfortable setting. Research conducted by Karasel et al. (2017) identified that teachers working with paternalistic school principals establish positive communication with the school managers and other teachers and maintain their relationship within the scope of common courtesy. Employees who can develop good communication with their managers have higher organizational commitment and job satisfaction levels (Anderson \& Martin, 1995). Besides, the employees identify more with their organizations (Kassing, 2000a), have a higher organizational commitment (Haskins, 1996), and as a result of this, they articulate their dissident views to their managers directly (Kassing, 2000a) in organizations where there is high freedom of 
speech. In another study (Sadykova \&Tutar, 2014), it is reported that the level of employees' upward dissent will increase with an increase in the managers' democratization level. In another study conducted by Oral-Ataç (2015), a positive relationship exists between employees' organizational dissent and organizational democracy perceptions. Employees with a high organizational democracy perception prefer an upward dissent strategy. An employee who thinks that one can express oneself freely in the organization commits to work more and becomes more productive. Employees are in an expectation of environments created where they can dissent (Kassing, 1997b). Hence, they prefer organizational settings where they can express themselves freely. Mentioned organizational environments are asserted to contribute to the increase in employees' job satisfaction and organization commitment (Gorden \& Infante, 1987). It is reported that there is a high-level relationship between organizational communication and job satisfaction (De Nobile \& McCormik, 2008), and managers promoting the employees to express their views in organizational matters increase employees' job satisfaction (Gorden, Infante \& Graham, 1988). Therefore, paternalistic management can increase employees' job satisfaction levels, and thus employees can prefer a relatively more upward dissent strategy. Findings of the research made by Kassing (1988) support this claim. In the relevant study, high job satisfaction levels positively correlate with upward dissent and latent dissent. It is also possible to run into other research findings that support this claim (Pienaar, Sieberhagen \& Mostert, 2007; Uhl-Bien et al., 1990; Yetim \& Yetim, 2006). In the mentioned studies, it is identified that the PL behaviours exhibited by managers increase employees' job satisfaction levels and decrease the intentions to leave the job. It is also possible to reach the result in the mentioned studies. With the understanding of paternalistic management, employees do 
not leave the organization they work for and articulate their dissident views by staying within the organization.

Another finding concerning the second question in this research is that the moral leadership dimension of $\mathrm{PL}$, along with the benevolent leadership dimension, predicts upward dissent. The moral leader has a sense of justice predominantly, tries to keep his promises, does not misuse his authority, and does not take advantage of the weaknesses of his followers for his benefit. It is stated that the followers appreciate and internalize this behaviour of the leader and take this virtuous manner of the leader as an example (Farh et al., 2006), respect the leader more, and identify themselves more with the leader (Farh \& Cheng, 2000). Given that the members of the organization who have high organizational identification levels are in a tendency to articulate their dissident views directly to their managers (Kassing, 2000a), it can be said that the moral leadership behaviours exhibited by primary school principals made a positive contribution on the organizational identification levels of teachers and this may influence the obtainment of the result in the present study that the moral leadership dimension predicts upward dissent. On the other hand, it has been put forward by various studies (Çalışkan, 2010; Köksal, 2011) that PL is positively correlated with the sense of justice, which can be considered as an essential component of moral leadership, and that PL predicts organizational justice. When dissent is regarded as having a prediction that enhances organizational justice (Özdemir, 2010), moral leadership likely predicts upward dissent. Therefore, this mentioned situation can be said to affect the obtainment of the finding in the present study, as well.

One of the findings concerning the second question in this research is that the authoritarian leadership dimension predicts 
upward dissent, as was the case with benevolent leadership and moral leadership dimensions. However, according to the order of importance in this prediction, it is striking that the authoritarian leadership dimension comes after morality and benevolence dimensions. Accordingly, it can be said that the leader's display of moral and benevolent behaviours can cause more dissident behaviours by the employees, according to the authority. In the present study, it is seen within the scope of authoritativeness that the primary school principals demand unconditional obedience from teachers towards the decisions principals make; therefore, they hold themselves at a distance in their relationships with the teachers, and they want every matter related to school under their control. These kinds of behaviours principals exhibit are likely to hinder the teachers' freedom of speech. In research conducted on this subject by Zhang, Huai and Xie (2015), it is identified that authoritarian leadership affects the employees' freedom of speech negatively. The teachers likely deterred from the freedom of speech exhibit dissident behaviours. In addition to this, it is understood that authoritarian leaders do not assume democratic behaviours in decision-makings. Primary school principals not considering teachers' views when deciding may have caused teachers to exhibit dissident behaviours. This seems by the "decision-making" claim taking place in the "typology of the events triggering organizational dissent" by Kassing (1997b). Kassing (1997b) asserts that organizational dissent starts when followers challenge their leaders' decision-making logic. On the other hand, given that the authoritarian leadership negatively affects the employees' job satisfaction (Anwar, 2013; Chou, 2012), organizational citizenship, and organizational commitment levels (Rehman \& Afsar, 2012), authoritarian leadership behaviours displayed are likely to cause teachers to display dissident behaviours. It can be said that by primary 
school principals, the abovementioned situations predict the obtainment of the finding in the present study.

Another finding concerning the second question in this research is that only the moral leadership and exploitative leadership sub-dimensions of PL predict the latent dissent, a sub-dimension of organizational dissent. It had been stated before that the teachers might prefer upward dissent strategy over latent dissent since the moral leadership behaviours displayed by the primary school principals affect their organizational identification levels. In other respects, it is identified that exploitative leadership predicts latent dissent. In the present study, it is seen within the scope of exploitation that the primary school principals use particular strategies to subdue the dissent towards themselves; that way they expect commitment from teachers as a result of the close relationship they establish with them, and they expect support from the teachers they trust (Even though the exploitative leadership dimension is thought to be the opposite of the moral leadership dimension, when the behaviours at the level of exploitative leadership are examined, it will be seen that exploitative leadership is mostly related with political leadership. Therefore, it is thought that it will not be ethically correct to evaluate the behaviours at the level of exploitative leadership dimension. In other words, it can be stated that the leader behaves politically in the exploitative leadership.). In the present study, when the exploitative leadership behaviours displayed by primary school principals are examined, it can be asserted that the principals expect teachers to be loyal to themselves. In research conducted by Leck and Saunders (1992), it is identified that employees with a high loyalty level do not contemplate leaving their work despite the low job satisfaction that they can experience. Instead, they prefer to articulate their contradictory views in the organizational environment while they 
continue working, and they do so to their managers openly. From this point onwards, it can be stated that teachers may prefer latent dissent strategy less as primary school principals keep exhibiting exploitative leadership behaviours. Therefore, this situation can be said to predict the obtainment of the finding in the present study.

This research emphasizes the importance of paternalistic leadership in increasing teachers' perceptions of organizational creativity. Our research is the first research about the potential effects of paternalistic leadership on organizational creativity. In Turkey, where the educational system is managed centrally, teachers may feel under pressure as they are stuck between central administration policies and local dynamics. In this context, it is considered that the supportive approach of school principals towards teachers will be necessary for Turkish primary schools to reduce the pressure. It is understood that the said supportive environment effectively creates an environment where teachers can better express their contradictory views. It has been reported in our research that paternalistic leadership positively affects teachers' perceptions of organizational dissent. We can interpret this result in two ways. The first is that paternalistic leadership, with its authoritarian dimension, can cause teachers to act in dissent. The second is related to the fact that teachers can feel freer with the supportive approach of school principals. A research result (Croucher, Parrott, Zeng \& Gomez, 2014) shows a positive relationship between freedom of speech in the workplace and the dissent expressed to managers. Therefore, the fact that paternalistic leadership increases teachers' perceptions of organizational dissent can be evaluated positively. The fact that the dissent can be made will contribute to the understanding of democratic management in schools. 
In this study, several limitations exist. This research is limited to the teachers' perceptions in official primary schools in the central district of Mardin province and eight district centers in the 2016-2017 academic year. Also, research findings are limited to data collected from scales of measurement. It was assumed that the teachers participating in the study were volunteers and sincerely reflected their views while answering the questions in the scales. Future research could investigate the relationships between paternalistic leadership and other organizational variables. Future research can be done at different school levels and by expanding the population. The study is based on teacher perceptions. Future research could be done according to the school principals' perceptions.

Following recommendations can be put forward towards practitioners based on the obtained conclusion. School principals should exhibit a high level of benevolent leadership behaviours that can increase the teachers' organizational creativity levels, such as creating a family environment at school, being tolerant to teachers promoting teachers to take initiatives. Principals should exhibit a high level of moral leadership behaviours that can increase the teachers' organizational creativity levels, such as treating fairly, paying attention to the professional development of teachers, and maintaining harmonious relations with teacher groups of different views. It is contemplated that a strong interaction between teachers and the principal who displays benevolent leadership behaviours will positively reflect on the teachers articulating their dissident opinions openly. For that, though, it is thought that removing the obstacles which block the way to the teachers' freedom of speech is a must. Thus, teachers' organizational identification and dedication levels will increase, the communication between the principals and teachers will 
reach a healthy level, and most importantly, teachers' organizational commitment and job satisfaction levels will rise.

School principals should treat fairly when distributing awards to teachers, protect their teachers against the unfair criticisms coming from out of the school, use their authority to profit from it, and not attribute the successes of the teachers to themselves. Principals should include teachers in the decision-making process in matters concerning them; give an opportunity, when necessary, to teachers to question these decisions; and brief all teachers, when necessary, concurrently on judgments concerning them. In addition to those, principals should not expect teachers to obey the decisions they made unconditionally and every matter related to school to be under their control. Principals should clearly state the criteria that will be used when considering teachers' opinions by evaluating the applicability of the views suggested together with the teachers through the brainstorming sessions aimed at producing ideas by the teachers. Principals should not take the dissent towards themselves as a threat and struggle to subdue it and should stay away from the kind of behaviours that can lead to discrimination among teachers, such as expecting teachers they trust to support them.

\section{References}

Agrell, A., \& Gustafson, R. (1994). The team climate inventory (TCI) and group innovation: A psychometric test on a Swedish sample of work groups. J Occup Organ Psychol,67(2), 143-151.

Ağalday, B., Özgan, H., \& Arslan, M.C. (2014). The perceptions of the administrators working in primary and secondary schools related to the organizational dissent. Pegem Journal of Education and Instruction, 4(3), 35-50. 
Amabile, T. M. (1988). A model of creativity and innovation in organizations. In B. Staw and R. Sutton (Eds.), Research in organizational behavior (pp.123-167.). Greenwich, CT: JAI Press.

Amabile, T. M. (1997). Motivating creativity in organizations: On doing what you love and loving what you do. California Management Review, 40(1), 39-58.

Amabile, T. M. (1998). How to kill creativity. Harvard Business Review, 76(5), 76-87.

Amabile, T.M., Conti, R., Coon, H., Lazenby, J., \& Herron, M. (1996). Assessing the work environment for creativity. Academy of Management Journal, 39, 1154-1184.

Amabile, T. M., Schatzel, E., Moneta, G., \& Kramer, S. (2004). Leader behaviors and the work environment for creativity: Perceived leader support. Leadership Quarterly, 15(1), 5-32.

Anderson, C. M., \& Martin, M. M. (1995). Why employees speak to coworkers and bosses: Motives, gender, and organizational satisfaction. Journal of Business Communication, 32(3), 249-265.

Andriopoulos, C. (2001). Determinants of organizational creativity: A literature review. Management Decision, 39(10), 834-840.

Anwar, H. (2013). Impact of paternalistic leadership on employees' outcome- A study on the banking sector of Pakistan. IOSR Journal of Business and Management,7(6), 109-115.

Anyanwu, C., \& Oad, S. (2016). Entrepreneurial leadership and organizational creativity in the collectivist context: The moderating role of emotional intelligence. International Journal of Management and Administrative Sciences, 4(2), 1-12.

Aycan, Z. (2001). Human resource management in Turkey: Current issues and future challenges. International Journal of Manpower, 22(3),252-260.

Aycan, Z. (2006). Paternalism: Towards conceptual refinement and operationalization. In K. S. Yang, K. K. Hwang and Kim (Eds.), Scientific advances in indigenous psychologies: Empirical, 
philosophical, and cultural contributions (pp. 445-466). London: Sage Ltd.

Aycan, Z., \& Fikret-Paşa, S. (2003). Career choices, job selection criteria, and leadership preferences in a transitional nation: The case of Turkey. Journal of Career Development, 30(2), 29-144.

Aycan, Z., \& Kanungo, R.N. (2000). Toplumsal kültürün kurumsal kültür ve insan kaynakları uygulamaları üzerine etkileri (in Turkish). Aycan, Z. (ed.). Akademisyenler ve profesyoneller bakış açısıyla Türkiye'de yönetim, liderlik ve insan kaynakları uygulamaları (ss: 25-57). Ankara: Türk Psikologlar Derneği Yayınları.

Aycan, Z., Kanungo, R. N., \& Sinha, J.B.P. (1999). Organizational culture and human resource management practices: The model of culture fit. Journal of Cross-Cultural Psychology, 30(4), 501-516.

Aycan, Z., Kanungo, R.N., Mendonca, M. Yu, K., Deller, J. Stahl, G., \& Kurshid, A. (2000). Impact of culture on human resource management practices: A ten country comparison. Applied Psychology: An International Review, 49(1),192-220.

Aydintan, B. (2016). Relationship between emotional intelligence and paternalistic leadership: A field study on the Turkish university students. International Journal of Business and Management Invention, 5(12), 98-102.

Atwater, L., \& Carmeli, A. (2009). Leader-member exchange, feelings of energy and involvement in creative work. The Leadership Quarterly, 20(3), 264-275.

Basadur, M. (1997). Organizational development interventions for enhancing creativity in the workplace. Journal of Creative Behavior, 31(1), 52-97.

Bell-Robinson, V.D. (2016). Exploring the relationship between self-efficacy and dissent among college student organizational members: A mixed-methods study (Unpublished doctoral thesis). Department of Educational Leadership, Miami University. 
Bharadwaj, S., \& Menon, A. (2000). Making innovation happen in organizations: Individual creativity mechanism, organizational creativity mechanism or both? Journal of Product Innovation Management, 17, 424-434.

Bouda, D. (2015). The expression of organizational dissent among subsaharan African student migrants in the United States (Unpublished master's thesis). Minnesota State University.

Burns, T., \& Wagner, C. (2013). Organizational dissent: A form of feedback. NASSP Principal Leadership, 14(4) 28-32.

Cansoy, R., Polatcan, M., \& Parlar, H. (2020). Paternalistic school principal behaviours and teachers' participation in decision making: The intermediary role of teachers' trust in principals. Research in Educational Administration \& Leadership, 5(2), 553584. doi: $10.30828 / \mathrm{real} / 2020.2 .8$

Cheng, B.S. (1995). The relationship between parent's authority and leadership behaviors: A case study of president of a Taiwanese enterprise.Report on Special Topics, National Science Committee.

Cheng, B.S., Chou, L.F., \& Farh, J. L. (2000). Paternalistic leadership scale: Construction, and measure of a triple model. Indigenous Psychology Journal, 14, 3-64.

Cheng, B. S., Chou, L. F., Wu, T. Y., Huang, M. P., \& Farh, J. L. (2004). Paternalistic leadership and subordinate responses: Establishing a leadership model in Chinese organizations. Asian Journal of Social Psychology, 7, 89-117.

Chou, H.J. (2012). Effects of paternalistic leadership on job satisfaction: Regulatory focus as the mediator. The International Journal of Organizational Innovation, 4(4), 62-85.

Cerit, Y. (2012). The relationship between paternalistic leadership and satisfaction from administrator and work. Ondokuz Mayıs University Journal of Education Faculty, 31(2), 35-56.

Cerit, Y. (2013). The relationship between paternalistic leadership and bullying behaviours towards classroom teachers. Educational Sciences: Theory and Practice,13(2), 839-851. 
Cerit, Y., Özdemir, T., \& Akgün, N. (2011). Classroom teachers' opinions toward primary school principal fulfilment of paternalistic leadership behaviors in terms of some demographic variables. AIBU Journal of the Faculty of Education, 11(1), 87-99.

Chen, X.P., Eberly, M.B., Chiang, T.J., Farh, J.L., \& Cheng, B.S. (2011). Affective trust in Chinese leader: Linking paternalistic leadership to employee performance. Journal of Management, 40(3), 796-819.

Chou, H.J. (2012). Effects of paternalistic leadership on job satisfaction: Regulatory focus as the mediator. The International Journal of Organizational Innovation, 4(4), 62-85.

Croucher, S. M., Parrott, K., Zeng, C., \& Gomez, O. (2014) A crosscultural analysis of organizational dissent and workplace freedom in five European economies. Communication Studies, 65(3), 298-313, doi: 10.1080/10510974.2013.811430

Çalışkan, S.C. (2010). The interaction between paternalistic leadership style, organizational justice and organizational citizenship behavior: A study from Turkey. China-USA Business Review, 9(10), 67-80.

Çavuş, M.F. (2006). An application in manufacturing industry on the effects of organizational creativity andinnovativeness of employee empowerment applications in companies (Unpublished doctoral thesis). Selçuk University Social Science Institute, Konya.

Çelik, Z., Yurdakul, S., Bozgeyikli, H., \& Gümüş, S. (2017). Eğitime bakış 2017: İzleme ve değerlendirme raporu (in Turkish). Ankara: EğitimBir-Sen Stratejik Araştırmalar Merkezi.

Dağlı, A. (2015). Adaptation of organizational dissent scale into Turkish language: The study of validity and reliability. Electronic Journal of Social Sciences, 14(53), 198-218.

Dağlı, A. (2017). Investigating the relationship between organizational dissent and life satisfaction. Universal Journal of Educational Research, 5(4), 600-607. 
Dağlı, A., \& Ağalday, B. (2014a). The opinions of the teachers related to the types of organizational dissident behaviours. Electronic Journal of Social Sciences, 13(50),112-128.

Dağl1, A., \& Ağalday, B. (2014b). The opinions of the teachers related to the effects of organizational dissent. The Journal of Academic Social Sciences, 2(1), 170-182.

Dağlı, A., \& Ağalday, B. (2015). The opinions of the teachers related to the causes of organizational dissent. Elementary Education Online, 14(3), 885-898.

Dağlı, A., \& Ağalday, B. (2017). Developing a headmasters' paternalistic leadership behaviours scale in Turkey. Journal of Education and Practice, 8(30), 190-200.

De Nobile, J.J., \&McCormick, N. (2008). Organizational communication and job satisfaction in Australian Catholic primary schools. Educational Management and Leadership, 36(1), 101-122.

Develi, N. (2008). Family enterprises, management and organization problems encountered in family enterprises: Mersin case. Pamukkale University School of Social Sciences, 3(45), 23-45.

Dimmock, C. (1999). The management of dilemmas in school restructuring: A case analysis. School Leadership and Management, 19, 97-113.

Einsteine, P., \& Hwang, K. P. (2007). An appraisal for determinants of organizational creativity and impacts on innovative behavior. Proceedings of the 13th Asia Pacific Management Conference, Melbourne, Australia, 1041-1055.

Ekmen, F., \& Okçu, V. (2021). The relationship between paternalistic leadership behaviors of school administrators and pre-school teachers' job satisfaction, 8(6), 142-164. doi:10.46827/ejes.v8i6.3776

Ekvall, G. (1996). Organizational climate for creativity and innovation. European Journal of Work and Organizational Psychology, 5(1), 105123. 
Ekvall, G., \& Ryhammar, L. (1998). Leadership style, social climate and organizationaloutcomes: A study of a Swedish University College. Creativity and Innovation Management, 7(3), 126-130.

Erben, G. S. (2004). Toplumsal kültür aile kültürü etkileşimi bağlamında paternalizm boyutuyla işletme kültürü: Türkiye örneği (in Turkish). 1. Aile İsletmeleri Kongresi, (17-18 Nisan), (Ed.: Koçel, T.), İstanbul: İstanbul Kültür Üniversitesi Yayınları: 345-356.

Erben, G. S., \& Güneşer, A.B. (2008). The relationship between paternalistic leadership and organizational commitment: Investigating the role of climate regarding ethics. Journal of Business Ethics, 82, 955-968.

Ersoy, N.C., Born, M., Derous, E., \&Molen, H.T. (2012). The effect of cultural orientation and leadership style on self-versus otheroriented organizational citizenship behaviour in Turkey and the Netherlands. Asian Journal of Social Psychology, 15, 249-260.

Farh, J. L., \& Cheng, B.S. (2000). A cultural analysis of paternalistic leadership in Chinese organizations. London: Macmillan.

Farh, J.L., Cheng, B.S., Chou, L.F., \& Chu, X.P. (2006). Authority and benevolence: Employees' responses to paternalistic leadership in China. In A.S. Tsui, Y. Bian andL. Cheng (Eds.), China's domestic private firms: Multidisciplinary perspectives on management and performance (pp.230-260). New York: Sharpe.

Ford, C. R. (1996). A theory of individual creative action in multiple social domain. Academy of Management Review, 21(4), 1112-1142.

Fraenkel, W., Wallen, N., \& Hyun, E. (2012). How to design and evaluate research in education. McGraw-Hill.

Fullan, M. (2002). The change leader. Educational Leadership, 8, 16-22.

Gelfand, M.J., Erez, M., \& Aycan, Z. (2007). Cross-cultural organizational behavior. Annual Review of Psychology, 58, 479514.

Gorden, W. I., \& Infante, D. A. (1987). Employee rights: Content, argumentativeness verbal aggressiveness and career satisfaction. In C.A.B. Osigweh (Ed.). Communicating employee 
responsibilities and rights: A modern management mandate (pp. 149163). Westport, CT: Greenwood.

Gorden, W.I., Infante, D.A., \& Graham, E.E. (1988). Corporate conditions conducive to employee voice: A subordinate perspective. Employee Responsibilities and Rights Journal, 1, 101111.

Graham, J.W. (1986). Principled organizational dissent: A theoretical essay. Research in Organizational Behavior, 8, 1-52.

Gu, Q., Tang, T.L., \& Jiang, W. (2015). Does moral leadership enhance employee creativity? Employee identification with leader and leader-member exchange $(\operatorname{lm} x)$ in the Chinese context. $J$ Bus Ethics, 126, 513-529.

Gunter, H. M. (2001). Leaders and leadership in education. Dordrecht: Kluwer Academic Publishers.

Hallinger, P. (2003). Leading educational change: Reflections on the practice of instructional and transformational leadership. Cambridge Journal of Education, 33, 329-351.

Harris, A. (2004). Editorial: School leadership and school improvement: A simple and a complex relationship. School Leadership and Management, 24, 3-5.

Hatipoğlu, Z., Akduman, G., \&Demir, B. (2019). The effect of paternalistic leadership style on employee task performance and emotional commitment. Journal of Business Research, 11(1), 279-292. https://doi.org/10.20491/isarder.2019.599

Hayek, M., Novicevic, M. M., Humphreys, J., \& Jones, N. (2010). Ending the denial of slavery in management history: Paternalistic leadership of Joseph Emory Davis. Journal of Management History, 16(3), 367-379.

Hegstrom, T.G. (1991). Mimetic and dissent conditions in organizational rhetoric. Journal of Applied Communication Research, 18, 141-152.

Hofstede, G. H. (2006). What did Globe really measure? Researchers' minds versus respondents' minds. Journal of International Business Studies, 37(6), 882-896. 
Jones, N. (1999). The changing role of the primary school head. Educational Management and Administration, 27, 441-451.

Jung, D. I. (2001). Transformational and transactional leadership and their effects on creativity in groups. Creativity Research Journal, 13(2), 185-195.

Inand1, Y., \& Tunc, B., Yucedaglar, A., \& Kilic, S. (2020). The relationship of school administrators' leadership styles with organizational dissent and resistance to change according to perceptions of teachers, International Online Journal of Educational Sciences, 12(5), 287-302.

İraz, R. (2010). Yaratıcılık ve yenilik bağlaminda girişimcilik ve kobiler (in Turkish). Konya: Çizgi Kitabevi.

Kabasakal, H., \&Bodur, M. (1998). Leadership, values, and institutions: The case of Turkey. Paper presented at Western Academy of Management Conference, Istanbul, Turkey, June.

Kallio, T. J., \& Kallio, K.M. (2011). Organisatornenluovuus: Hypestäkohtiluovuuden mahdollistaviaorganisaatiorakenteita. LiiketaloustieteellinenAikakauskirja, 11(1), 33-64.

Karasel, N., Altınay, Z. Altınay, F., \& Dağlı, G. (2017).Paternalist leadership style of the organizational trust. Quality \& Quantity International Journal of Methodology, 1-20. https://doi.org/10.1007/s11135-017-0580-x.

Kassing, J. W. (1997a). Articulating, antagonizing, and displacing: A model of employee dissent. CommunicationStudies,48(4), 311332.

Kassing, J. W. (1997b). Development and validation of the organizational dissent scale (Unpublished doctoral dissertation). Kent State University.

Kassing, J. W. (1998). Development and validation of the organizational dissent scale. Management Communication Quarterly, 12(2), 183-229.

Kassing, J. W. (2000a). Exploring the relationship between workplace freedom of speech, organizational identification, and 
employee dissent. Communication Research Reports, 17, 387396.

Kassing, J. W. (2000b). Investigating the relationship between superiorsubordinate relationship quality and employee dissent. Communication Research Reports, 17, 58-70.

Kassing, J. W. (2002). Speaking up: Identifying employees' upward dissent strategies. Management Communication Quarterly, 16(2), 187-209.

Kim, U. M. (1994). Significance of paternalism and communalism in the occupational welfare system of Korean firms: A national survey. In U. Kim, H.C. Triandis, C. Kagitcibasi, S. Choi, \& G. Yoon (Eds.), Individualism and collectivism: Theory, method and applications (pp. 251-266). London, England: SAGE.

Kline, R.B. (2011). Methodology in the social sciences: Principles and practice of structural equation modelling ( $3 r d$ ed.). Guilford Press.

Korucuoğlu, T., \& Şentürk, İ. (2020). The relationship between organizational political games and organizational dissent. Hacettepe University Journal of Education, 35(2), 428-447. doi: 10.16986/HUJE.2018045306

Köksal, O. (2011). An empirical study towards determination of the relationship between paternalism and perceived organizational justice. Cumhuriyet University Journal of Economics and Administrative Sciences, 12(2), 159-170.

Kurt, İ. (2013). A research study on the relationship between paternalistic leadership and employee creative work involvement perceptions. Journal of Social and Human Sciences, 5(1), 321-330.

Lakomski, G. (2008). Functionally adequate but casually idle: w(h)ither distributed leadership. Journal of Educational Administration, 46(2), 159-171.

Leck, J.D., \& Saunders, D.M. (1992). Hirschman's loyalty: Attitude or behavior?. Employee Responsibilities and Rights Journal, 5, 219230. 
Leithwood, K., \& Jantzi, D. (1999). The relative effects of principal and teacher sources on student engagement with school. Educational Administration Quarterly, 35, 679- 706.

Leithwood, K., Steinbach, R., \& Ryan, S. (1997). Leadership and team learning in secondary schools. School Leadership and Management, 17, 303-325.

Martinez, P.G. (2003). Paternalism as a positive form of leadersubordinate exchange: $\quad$ Evidence from Mexico. Journal of Iberoamerican Academy of Management, 1, 227-242.

Mayer, R.C., Davis, J.H., \& Schoorman, F.D. (1995). An integrative model of organizational trust. Academy of Management Review, 20, 709-734.

Mert, P., \& Ozgenel, M. (2020). A relational research on paternalist leadership behaviors perceived by teachers and teachers' performance. Educational Policy Analysis and Strategic Research, 15(2), 41-60. doi: 10.29329/epasr.2020.251.

Mete, Y. A., \& Serin, H. (2015). Relationship between school administrators' paternalist leadership behaviours and teachers' organizational citizenship and organizational cynicism behaviours. HAYEF Journal of Education, 12(2), 147.

McKnight, D. H., Cummings, L. L., \& Chervany, N. L. (1998). Initial trust formation in new organizational relationships. Academy of Management Review, 23, 473-490.

Miller, F.G., \& Wertheimer, A. (2007). Facing up to paternalism in research ethics. Hasting Center Report, 37(3), 24-34.

Mumford, M. D., \& Connelly, M. S. (1999). Leadership. In M. A. Runcove S. R. Pritzker (Eds.), Encyclopedia of creativity (pp. 139146). San Diego: Academic Press.

Mumford, M. D., Ginamaire, M. S., Gaddis, B., \& Strange, J. M. (2002). Leading creative people: Orchestrating expertise and relationships. Leadership Quarterly,13, 705-750.

Mumford, M.D., \& Gustafson, S.B. (1988). Creativity syndrome: Integration, application and innovation. Psychological Bulletin, $103,27-43$. 
Niu, C.P., Wang, A.C., \& Cheng, B.S. (2009). Effectiveness of a moral and benevolent leader: Probing the interactions of the dimensions of paternalistic leadership. Asian Journal of Social Psychology, 12, 32-39.

Okçu, V., Ergül, H., \& Ekmen, F. (2020). Examining the relationship between the paternalist leadership behaviour of school principals and the levels of organizational trust and motivation, according to the perceptions of teachers (path analysis study). The Journal of International Social Research, 13(73), 755-770.

Oldham, G. R., \& Cummings, A. (1996). Employee creativity: Personal and contextual factors at work. Academy of Management Journal, 39(3), 607-634.

Oral-Ataç, L. (2015). The relationship between organizational democracy and organizational dissent: A research on white collars (Unpublished doctoral thesis). Manisa Celal Bayar University Social Science Institute, Manisa.

Özdemir, M. (2010). The opinions of administrators and teachers working in public high schools in Ankara province on organizational dissent (Unpublished doctoral thesis). Ankara University Educational Sciences Institute, Ankara.

Özgenel, M., \& Canulans1, R. (2021).The effect of paternalist leadership behaviors of school principals on organizational happiness. Education \& Technology, 3(1) 14-31.

Özgenel, M., \& Dursun, İ. E. (2020). The effects of school principals' paternalistic leadership behaviours on school culture. Journal of Social, Human and Administrative Sciences, 3(4), 284-302.

Paşa, S. F., Kabasakal, H., \& Bodur, M. (2001). Society, organizations, and leadership in Turkey. Applied Psychology: An International Review, 50(4), 559-589.

Pellegrini, E. K., \& Scandura, T. A. (2006). Leader-member exchange (LMX), paternalism and delegation in the Turkish business culture: An empirical investigation. Journal of International Business Studies, 37(2), 264-279. 
Pellegrini, E. K., Scandura, T. A., \& Jayaraman, V. (2010). CrossCultural generalizability of paternalistic leadership: an expansion of leader-member exchange theory (LMX). Group and Organization Management, 35, 391-420.

Pienaar, J., Sieberhagen, C. F., \& Mostert, K. (2007). Investigating turnover intentions by role overload, job satisfaction, and social support moderation. Journal of Industrial Psychology, 33(2), 62-67.

Redding, S. G. (1990). The spirit of Chinese capitalism. New York: Walter de Gruyter \& Co.

Redding, W. C. (1985). Rocking boats, blowing whistles, and teaching speech communication. Communication Education, 34, 245-258.

Redmond, M. R., Mumford, M. D., \& Teach, R. (1993). Putting creativity to work: Effects of leader behavior on subordinate creativity. Organizational Behavior and Human Decision Processes, $55,120-151$

Rehman, M., \& Afsar, B. (2012). The impact of paternalistic leadership on organization commitment and organization citizenship behaviour. Journal of Business Management and Applied Economics, 5,1-12.

Riaza, M., Junejo, M. A., \& Shar, A. H. (2020). Leadership styles: Relationship with organizational dissent and conflict management mediation analysis via $\mathrm{Cb}$-Sem approach. International Transaction Journal of Engineering, Management, $\mathcal{E}$ Applied Sciences \& Technologies, 11(11), 1-12.

Sadykova, G., \& Tutar, H. (2014). A study on the relationship between organizationaldemocracy and organizational dissent. The Journal of Business Science, 2(1), 1-16.

Sheer, V.C. (2010). Transformational and paternalistic leaderships in Chinese organizations: Construct, predictive, and ecological validities compared in a Hong Kong sample. Intercultural Communication Studies, 19(1), 121-140.

Sheer, V. C. (2012). In search of Chinese paternalistic leadership: Conflicting evidence from samples of Mainland China and 
Hong Kong's small family businesses. Management Communication Quarterly, 27(1), 34-60.

Schein, E. H. (2004). Organizational culture and leadership. C.A., USA: Josey Bass.

Schermelleh-Engel, K., Moosbrugger, H., \& Müller, H. (2003). Evaluating the fit of structural equation models: Tests of significance and descriptive goodness-of-fit measures. Methods of Psychological Research Online, 8(2), 23-74.

Scott, S. G., \& Bruce, R. A. (1994). Determinants of innovative behavior: A path model of individual innovation in the workplace. Academy of Management Journal, 37(3), 580-607.

Shin, S. J., \& Zhou, J. (2003). Transformational leadership, conservation, and creativity: Evidence from Korea. Academy of Management Journal, 46, 703-714.

Sillins, H., \& Mulford, B. (2002). Leadership and school results.In K. Leithwood \& P. Hallinger (Eds.), Second International handbook of educational leadership and administration. (pp. 561-612). Dordrecht: Kluwer Academic.

Sternberg, R. J. (2005). A model of educational leadership: Wisdom, intelligence, and creativity synthesized. International Journal of Leadership in Education: Theory \& Practice, 8, 347-364.

Styhre, A., \& Sundgren, M. (2005). Managing Creativity in Organizations: Critique and Practices. Basingstoke: Palgrave Macmillan.

Taşdemir, İ., \& Atalmış, E. H. (2021). Examination of the relationship between paternalistic leadership behaviors and creative leadership traits. Sakarya University Journal of Education Faculty, 21(1), 84-103.

Tierney, P., Farmer, S. M., \& Graen, G. B. (1999). An examination of leadership and employee creativity: The relevance of traits and relationships. Personnel Psychology, 52, 591-620.

Timperley, H. S., \& Robinson, V. M. J. (2001). Achieving school improvement through challenging and changing teachers' schema. Journal of Educational Change, 6, 227-215. 
Uhl-Bien, M., Tiemey, P. S., Graen, G.B., \& Wakabayashi, M. (1990). Company paternalism and the hidden investment process: Identification of the "right type" for line managers in leading Japanese organizations. Group and organization Studies, 15, 414430.

Volmer, J., Spurk, D., \& Niessen, C. (2012). Leader-member exchange (LMX), job autonomy, and creative work involvement. The Leadership Quarterly, 23(3), 456-465.

Wang, A. C., \& Cheng, B. S. (2010). When does benevolent leadership lead to creativity? The moderating role of creative role identity and job autonomy. Journal of Organizational Behavior.

Wang, A. C., Kuo, S. Y., Cheng, B. S., \& Tsai, C.Y. (2009). Paternalistic leadership and creativity: The moderating role of leader's gender. Academy of Management Conference.

Westwood, R. I. (1997). Harmony and patriarchy: The cultural basis for paternalistic headship among the overseas Chinese. Organization Studies, 18(3), 445-480.

Woodman, R. W., Sawyer, J. E., \& Griffin, R. W. (1993). Toward a theory of organizational creativity. Academy of Management Review, 18(2), 293-321.

Yetim, N., \& Yetim, Ü. (2006). The cultural orientations of entrepreneurs and employees' job satisfaction: The Turkish small and medium sized enterprises (smes) case. Social Indicators Research, 77(2), 257-286.

Y1ld1z, K. (2013). The relationship between organizational commitment and organizational cynicism and organizational dissent. Turkish Studies, 8(6), 853-879.

Y1lmaz, E., \& Sünbül, A. M. (2008). Analysing the organizational creativity from the point of employees' alienation levels. 2. International Congress on Entrepreneurship, Manas University.

Yukl, G. A. (2010). Leadership in organizations (7th ed.). New Jersey: Prentice Hall Inc. 
Zhang, Y., Huai, M. Y., \& Xie Y. H. (2015). Paternalistic leadership and employee voice in China: A dual process model. The Leadership Quarterly, 26, 25-36.

\begin{abstract}
About the authors:
Bünyamin Ağalday is an assistant professor in the Department of Educational Sciences at Mardin Artuklu University, Turkey. His research interests include educational leadership, educational management, and organizational behavior. He has recently focused on virtuous leadership behaviors and conflict management skills of school principals.
\end{abstract}

Authorship credit details: Conceptualization- formulation or evolution of overarching research goals and aims. Methodologydevelopment of methodology. Formal analysis- application of statistical techniques to analyze study data. Investigation- conducting a research and investigation process. Resources- provision of study materials. Writing-original draft preparation. Writing- review and editing. E-mail: bunyaminagalday@artuklu.edu.tr

Abidin Dağlı is an associate professor of Educational Administration at Dicle University, Turkey. His research interests include educational leadership, organizational behavior. He has recently focused on servant leadership behaviors and favouritism behaviours of school administrators.

Authorship credit details: Conceptualization- formulation or evolution of overarching research goals and aims Methodologydevelopment methodology. Supervision- oversight and leadership responsibility for the research activity planning and execution, Investigation- conducting a research and investigation process, Writing- review and editing. E-mail: dagli@dicle.edu.tr 